\title{
BLOG E CAMPO DE PRESENÇA
}

\section{BLOG AND PRESENCE FIELD}

NORMA DISCINI*

RESUMO: A partir do exame a ser feito de um blog de humor, discutiremos mecanismos de construção do sentido que fundam a enunciação como uma presença que se orienta entre a realização e a atualização, para definir-se como um corpo móvel, a partir de um enunciado móvel. Entre valores de universo que, fortalecidos, supõem a predominância da abertura sobre a do fechamento, deve confirmar-se um estilo blogueiro, inclinado ao inacabamento de si e de seu discurso. Para isso contribui a transversalidade entre enunciados e atores, bem como o efeito cumulativo de humor: um humor que, ao relativizar avaliações pejorativas, inclinadas à exclusão e à triagem, faz o corpo movimentar-se também em direção à mistura - na alternância de movimentos, o ritmo que funda o campo de presença.

PALAVRAS-CHAVE: Blog. Enunciação. Corpo.

ABSTRACT: Starting from the analysis of a humoristic blog, we will discuss mechanisms of meaning construction that establish the enunciation as a presence which guides itself between the realization and the actualization, to define itself as a mobile body, from a mobile utterance. Among universe values which, strengthened, assume the predominance of the opening over the closing, it shall be confirmed a blogger's

* Docente da USP - Universidade de São Paulo.E-mail: normade@uol.com.br 
style, tilted to the unfinalizability of himself and of his speech. In order that, intersections contribute between utterances and actors, as well as the cumulative effect of humor: a humor which, when relativizing pejorative assessments, inclined to the exclusion and to the triage, also makes the body move towards to the mixture - in the alternating movements, it is the rhythm that founds the presence field.

KEYWORDS: Blog. Enunciation. Body.

\section{A mediatização na Web: o que é o blog ${ }^{1}$}

Página pessoal, atualizada periodicamente, em que os usuários podem trocar experiências, comentários etc., geralmente relacionados com uma determinada área de interesse - eis como, na rubrica relativa à internet, está definido o blog no dicionário (HOUAISS, 2009). Encontramos aí também menção ao blogueiro como um termo que diz respeito tanto ao autor do blog como "a qualquer pessoa que costuma acessar blogues". Por sua vez, sobre blogar, ação de criar um blog ou interagir por meio dele, encontramos este comentário em fonte diversa: "Blogar' permite que haja um diálogo de mão dupla em um fórum público, liderado por pessoas reais". Assim afirma a pesquisadora (TERRA, 2012, p. 21), que realça o caráter de "veículo opinativo" para o blog, enfatizado como texto que "exprime pontos de vista de quem os redige" (p. 22).

Sites de divulgação do conhecimento instrumentalizam-

1 Web, segundo o dicionário (HOUAISS, 2009), é o nome pelo qual a rede mundial de computadores internet se tornou conhecida a partir de 1991, quando se popularizou devido à criação de uma interface gráfica que facilitou o acesso e estendeu seu alcance ao público em geral. 
-se para definir o blog como "espaços individuais disponibilizados pelos bloggers", estes apresentados como determinado "sistema de criação e de edição de blogs"; ou como um "serviço que oferece ferramentas para indivíduos publicarem seus textos na Internet sem a necessidade de ter domínio técnico, de programação ou de software". ${ }^{3}$ Junto a informações dessa natureza, expressões explicativas a respeito do blog como componente da blogosfera se multiplicam: é um "diário virtual" - como meio de identificação do blog em suas origens; diz respeito a um "endereço virtual" - como concepção de ancoragem na Web do próprio blog; supõe uma atualização contínua - o que necessariamente compõe o blog; implica publicações feitas à moda de intervenções e nomeadas como posts ou postagens - as quais costumam ocorrer com regularidade, mas sem previsão exata (a cada dia; várias vezes ao dia, semanalmente etc.); tem como marca a existência de links (ligação) - os quais fazem a conexão de um blog com outros, "indicados' pelo autor ou pelo próprio blogger", bem como mantêm a conexão com outras mídias (a televisão, por exemplo); favorece determinada organização linear para os posts - costumeiramente elencados de "forma cronológica inversa" e com foco na temática privilegiada; acolhe a intervenção dos internautas - que, feita por meio dos posts, pode vir "de um número variável de pessoas, de acordo com a política do blog"4; apresenta como traço distintivo de sua materialidade a mistura de diferentes linguagens em sincretismo - entendido o sincretismo como a união entre segmentos verbais, visuais, sonoros, entre

2 Disponível em: 〈https://pt.wikipedia.org/wiki/Blog〉. Acesso em: 15 dez. 2015.

3 Disponível em: 〈http://www.infoescola.com/informatica/o-que-sao-blogs/〉. Acesso em: 15 dez. 2015. 
outros, processada para compor um sentido único; viabiliza condições para que o leitor opine junto ao que diz o autor e junto ao que dizem outros leitores; favorece a própria tipificação, que elenca os blogs em classes: os pessoais, os corporativos e organizacionais, os chamados de gênero, estes, entre os quais se incluem os humorísticos, os de notícia, os informativos, os de variedades, os últimos que contêm contos, poesias, artigos jornalísticos de opinião etc. É frequente, ainda, a referência feita ao fato de que o blog se caracteriza, como outros gêneros da Web, por compor-se segundo um hipertexto, assim explicitado por Pierre Lévy, estudioso da cibercultura: "Hipertexto é um texto em formato digital, reconfigurável e fluido. Ele é composto por blocos elementares ligados por links que podem ser explorados em tempo real na tela" (LÉVY, 2011, p. 27). Homologando o hipertexto ao conceito de um "hiperdocumento" que se constitui segundo a incorporação de "todas as categorias de signos (imagens, animações, sons etc.)", o pesquisador realça "o princípio da mensagem em rede móvel que caracteriza o hipertexto" (LÉVY, 2011, p. 27).

Nos entornos do blog, certamente postamo-nos próximos do que é costumeiramente

referido como comunidades digitais, que, beneficiadas pela evolução das ferramentas da comunicação on-line, encontram no blog um formato viabilizador do que é hábito nomear-se como democratização da publicação. É um processo que reduz as barreiras para que leitores se tornem escritores, segundo informações recorrentes sobre o blog, colhidas na Internet. Estamos, então, no domínio da Web 2.0 - termo que se refere à "segunda geração de serviços e aplicativos da Web e aos recursos, tecnologias e conceitos que permitem maior grau de interatividade e colaboração na utilização da internet", como afirma Terra (2012, p. 23), que 
completa: "A Web 2.0 difere da primeira geração da internet principalmente pelo dinamismo das interfaces, em contraposição às páginas praticamente estáticas da Web 1.0" (p. 23).

0 blog - entendemos ser apenas uma das facetas do segundo dilúvio, aquele das informações, como lembra Pierre Lévy (2011, p. 13), apoiado em outros estudos. Referindo-se à "bomba das telecomunicações", o pesquisador completa:

As telecomunicações geram esse novo dilúvio por conta da natureza exponencial, explosiva e caótica de seu crescimento. A quantidade bruta de dados disponíveis se multiplica e se acelera. A densidade dos links entre as informações aumenta vertiginosamente nos bancos de dados, nos hipertextos e nas redes. Os contatos transversais entre os indivíduos proliferam de forma anárquica. É o transbordamento caótico das informações, a inundação de dados, as águas tumultuosas e os turbilhões da comunicação, a cacofonia e o psitacismo ensurdecedor das mídias, a guerra das imagens, as propagandas e as contrapropagandas, a confusão dos espíritos (LÉVY, 2011, p. 13).

Se psitacismo é termo que apresenta como primeiro sentido dicionarizado uma "perturbação psíquica que consiste em repetir palavras sem ter ideia do seu significado" (HOUAISS, 2009), a inclinação ao uso pejorativo do termo já se esboça no interior da exposição feita por Lévy. Um princípio de pejoração toca desse modo a natureza desses textos que circulam na internet e que compõem o "discurso eletrônico", tal qual designado por Marcuschi (2010), em estudo voltado ao hipertexto e aos gêneros digitais. 0 dicionário, por sua vez, ao registrar a extensão semântica do conceito de psitacismo, mediante registro feito de derivações e usos, realça estes desdobramentos: palavreado vazio e abundante; loquacidade, verborreia e, ainda, estudo por repetição mecânica; decoreba 
(HOUAISS, 2009). 0 princípio assinalado de avaliação pejorativa flui em discursos que, emparelhados à triagem de valores esboçada por Lévy, na citação reproduzida, consideram a mistura, que caracteriza os gêneros da Web, como nefasta. Mas a mistura deve confirmar-se como traço de identificação desses gêneros. Eis outra característica do blog, assim confinado com outros gêneros digitais: ele comporta um modo de dizer atrelado à mistura como regime de presença do enunciador.

Fontanille e Zilberberg (2001), ao desenvolver a noção de valor vinculado à presença, apresentam-na regida por valores de absoluto ou por valores de universo. Propõem, para uma presença que se deixa reger pela triagem, os valores de absoluto e, para uma presença que se deixa reger pela mistura, os valores de universo. Para exemplificar os últimos, os semioticistas citam, entre outros, este verso de Baudelaire, alusivo à prostituição: "Num espetáculo, num baile, todos desfrutam de todos", e acrescentam mais este: "O prazer de estar nas multidões é uma expressão misteriosa do desfrute da multiplicação do número" (FONTANILLE; ZILBERBERG, 2001, p. 57). Completam os semioticistas que "a prostituição, de que nos fala Baudelaire nas primeiras páginas de Fusées, parece justamente correspondente a um funcionamento hiperbólico dos valores de universo". Os gêneros digitais certamente remetem a uma presença inclinada para acolher os valores de universo, dos quais desponta a predominância da abertura sobre o fechamento e da mistura sobre a triagem. É uma mistura de enunciados, de enunciações, e dos próprios valores que fundam a presença exposta à transversalidade actancial favorecida pela internet.

Ao identificar o que entendem como as duas principais direções capazes de ordenar os sistemas de valores - de um lado, a exclusão-concentração regida pela triagem, de outro, a 
participação-expansão regida pela mistura - aqueles semioticistas ressaltam: "no caso dos valores de absoluto, parece que a triagem e o fechamento intervêm como operadores principais, tendo por benefício a concentração, enquanto os valores de universo pedem o concurso da mistura e da abertura, tendo por benefício a expansão" (FONTANILLE; ZILBERBERG, 2001, p. 47).

Entendemos que o contraste entre essas duas distintas direções ordenadoras de sistemas de valores sustenta a polêmica que tende a ser deflagrada no estudo feito por Lévy. É uma avaliação que costuma ocorrer em ensaios que alertam para consequências danosas advindas não do letramento digital, mas do uso excessivo feito da internet. Diante desse teor de crítica, certamente avizinhamo-nos de uma presença orientada por valores de absoluto, culturalmente determinados, que arbitram a medida do que é excessivo.

Mantendo à parte a discussão sobre o bem ou o mal relativos ao "dilúvio" de informações e à "explosão" comunicacional, fica, como componente para identificar o blog e como fundamento de um campo de presença, o regime da mistura. Entendemos que o corpo do blogueiro e a natureza dos enunciados que compõem o blog são orientados pela participação-expansão regida pela mistura, já de acordo com a expectativa criada pela esfera Web de comunicação.

Tal regime parece confirmar-se como relevante para a caracterização dos gêneros da Web em geral, constituídos conforme totalidades de enunciados pautados pela expansão participativa de presenças aglomeradas na textualização e no discurso. A expansão se comprova por meio da transversalidade actorial continuamente desdobrada na interação que, reproduzida em grande quantidade, é estabelecida entre enunciadores convidados a comparecer no blog com comen- 
tários e com comentários sobre comentários, entre outras modalidades de intervenção. A transversalidade, durativa na proliferação de actantes e atores, também se apresenta na prática da bricolagem intertextual, configurada como uma montagem que combina textos diversos no interior do blog. Assim se organiza o acolhimento regularmente feito, no interior do enunciado do blog, de segmentos textuais de outros blogs, de aplicativos de celular (como o Tinder), de excertos extraídos (em forma de vídeo) de programas de televisão etc.

Em princípio, aumenta nos gêneros digitais a extensidade como difusão do espaço da percepção de mundo, enquanto diminui e enfraquece a intensidade e a decorrente concentração da percepção. Nos blogs, assim como em gêneros afins, os valores de universo tendem a prevalecer em detrimento dos valores de absoluto, para que se componha o blogueiro como modo de presença dado na ordem da transversalidade das relações com o que vem e com o que está por vir do exterior: o outro, a alteridade discursivizada como o sujeito novo, que vem de fora e entra nos limites do blog para aí fazer postagens. Essa alteridade é discursivizada até como o próprio sujeito, organizador interno do seu blog, sujeito que se metamorfoseia num outro, na enunciação que é nova a cada vez que se enuncia, ao promover atualizações contínuas dessa página da Web. 0 princípio de difusão participativa traça expectativas de estilos: de gênero, de autor e (por que não?) de época.

\section{O blog como discurso: modos de existência do blogueiro}

O blog KIBELOCO figura, como blog de humor, entre os 
mais acessados pelos internautas ${ }^{5}$. A diagramação da página, no cabeçalho, apresenta regularmente rubricas que oferecem aberturas para a intervenção do leitor: "Séries/ O Kibe/ Anuncie/ Contato"'. No dia 07 de setembro de 2015, tal como registrado na introdução da página, uma sequência de fotomontagem oferece, por meio do sincretismo verbo-visual, charges vinculadas às comemorações do dia da Independência do Brasil e assinadas por Kibeloco. Cada uma delas apresenta o título recorrente - "Frase que D. Pedro I realmente deveria ter falado às margens do Rio Ipiranga". Entre tais charges, na reprodução feita de uma pintura sobre o "Grito do Ipiranga" mantida como fundo da fotomontagem, destaca-se a figura de D. Pedro, que, privilegiada pelos recursos da pintura, torna-se ambígua nos textos humorísticos. Seguem reproduzidos o texto-fonte da fotomontagem e a charge - esta que, na bricolagem, recorta a superfície, logo também o conteúdo da pintura. A charge faz isso ao inserir uma das falas daquele que, tornado o primeiro Imperador do Brasil, metamorfoseia-se num corpo em retirada como está sugerido no balão colado pela montagem ${ }^{7}$ :

5 Para outras informações sobre blogs de humor, temos esta referência: 〈http://www.sotrelando.com.br/ranking-dos-melhores-blogs-de-humor-do-brasil-com-mais-fas-nas-paginas-do-facebook/>. Acesso em: 16 dez. 2015.

6 Disponível em: «http://www.kibeloco.com.br/〉. Acesso em: 16 dez. 2015.

7 Maiores informações sobre o quadro de Pedro Américo estão contidas em: «https://historiandonanet07.wordpress.com/2011/01/16/\%E2\%80\%9Cindependencia-ou-morte\%E2\%80\%9D-de-pedro-americo/>. Acesso em: 16 dez. 2015. 
Figura 1 - Independência ou Morte, de Pedro Américo (1888)óleo sobre tela, $4,15 \mathrm{~m} \times 7,60 \mathrm{~m}$.

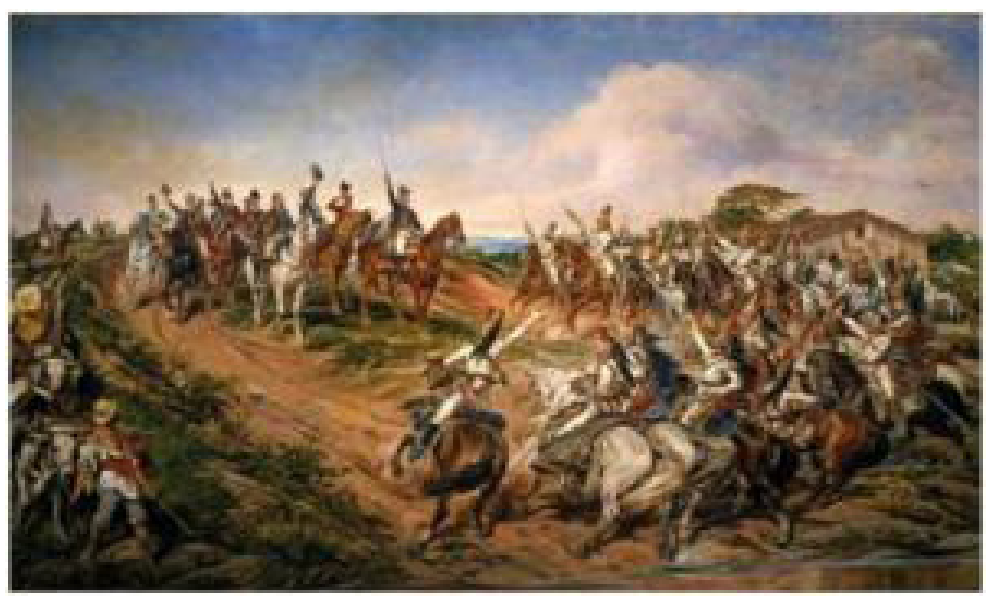

Fonte: Museu Paulista, São Paulo.

Figura 2 - Fotomontagem do blog Kibeloco feita a partir do quadro "Independência ou Morte", de Pedro Américo

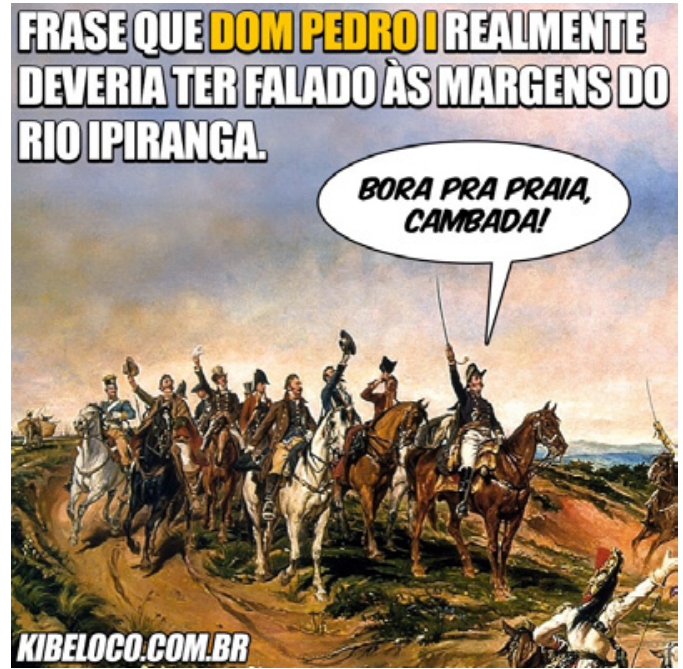

Fonte: Blog Kibeloco 
Entre tais charges apresentadas pelo blog, a fala de D. Pedro varia de um texto para outro, mantida a recontextualização feita do Grito da Independência, que teria sido proferido no dia 07 de setembro de 1822. Metamorfoseado, temos o grito que usa a expressão "Bora!" (Embora, vamos embora!), juntamente com o termo de chamamento, o vocativo lexicalizado por meio de "Cambada", que acusa um uso linguístico não afinado com a norma urbana dita de prestígio. Distanciado de uma variante linguística de prestígio, firma-se o segmento verbal no contraste com a imponência visual do texto-fonte, em que se movimentam o Príncipe Regente, sua guarda, soldados e outros atores reunidos no grande evento. 0 teor de crítica social afirma-se na nova ancoragem da mesma cena histórica: para isso contribui o marco temporal, 07 de setembro de 2015, data cravada num Brasil em crise, conforme noticia regularmente o jornal Folha de S. Paulo nas páginas de rosto e em páginas de Cadernos internos de edições que circundam o dia da postagem referida ${ }^{8}$.

A voz da sátira admite que resta ir embora para a praia, hábito de deslocamento arraigado na vida de certos grupos sociais e posto em prática por ocasião de feriados como é o 07 de setembro no Brasil. Assim, a isotopia actorial, espacial e temporal se organiza na ambiguidade favorecedora do efeito de humor: D. Pedro é e não é D. Pedro; as colinas do Ipiranga são e não são palco do Grito heróico; o 07 de setembro é e não é marco temporal de um momento glorioso de nossa história.

Para um reconhecimento interdiscursivo do que não é glorioso no Brasil em crise, encontramos comentários ilustrativos. Em editorial de capa, o jornal Folha de S. Paulo apresenta, à esquerda da rubrica Brasil em crise estas formu-

8 Disponível em: 〈http://edicaodigital.folha.com.br/home.aspx〉. Acesso em: 16 dez. 2015 
lações: "Trata-se de reconhecer as alarmantes dimensões da atual crise". [...] "Medidas extremas precisam ser tomadas". [...] "É imprescindível conter o aumento da dívida pública e a degradação econômica” (FSP, 13/ 09/2015). Esse é o ambiente semântico que, decorrente da sintagmática da mídia, atravessa, no elo midiático estabelecido pelo blog, temas e figuras eleitos por aquelas postagens feitas por meio de fotomontagem. Nas charges sobra então ao herói travestido pelo humor segurar uma espada apontada para o alto no gesto derradeiro de bravura, enquanto de seu corpo salta o balão que contém as falas derrisórias. Essas falas enfraquecem a intensidade heroica do corpo do ator do enunciado, D. Pedro, enquanto, ao misturá-lo com o corpo em fuga da crise, relativiza, por meio do tom de humor, a avaliação pejorativa sobre a própria crise e sobre supostos responsáveis por ela. Nas charges vizinhas de postagem, há esta outra fala de D. Pedro, em que sai recrudescida a ambiguidade actorial: D. Pedro é nossa Presidente da República e a recíproca é verdadeira, como efeito da bricolagem. $\mathrm{O}$ humor se sustenta na ambiguidade, ressaltando a cumplicidade entre os internautas que acessam o blog. Diz então "D. Pedro-Dilma": "Independência ou a meta. Chegando na meta, a gente dobra ela".

Temos aí a montagem criada a partir do pronunciamento feito pela Presidente da República e recortado da mídia que noticia a contemporaneidade de um "Brasil em crise". No dia 28 de julho de 2015, em declaração proferida durante evento do Pronatec Jovem Aprendiz, ao anunciar vagas, a Presidente afirmou: "Não vamos colocar meta. Vamos deixar a meta aberta, mas, quando atingirmos a meta, vamos dobrar a meta". ${ }^{9}$ ciar-novas-vagas-dilma-se-enrola-para-explicar-meta-do-pronatec.shtmlı. Acesso em: 16. dez.2015. 
A colagem acaba então por subverter, por meio da alusão intertextual, o ambiente de seriedade histórica próprio ao quadro. Cumpre-se a ambiguidade do riso ou uma "ambivalência" que resvala num riso "regenerador" (sem atingi-lo, porém) como descrito por Bakhtin (1987, p. 210). A charge, ao brincar com os contrastes históricos como marcos temporais e figuras actoriais em confronto - ano de 1822, data da Independência, 2015, data da postagem; D. Pedro, proclamador da Independência do Brasil, Dilma Roussef, Presidente de um "Brasil em crise" - imprime o tom sarcástico a partir do quadro histórico e faz fortalecer o corpo debochado a partir da memória heroica. Na mistura, aliada do efeito cômico, que subverte o texto de base, firma-se o próprio efeito de humor, prolongado nas outras charges elaboradas a partir do mesmo fundo, que é a descrição estética do momento de proclamação da Independência de nossa pátria.

Pensando em oscilações tensivas, estabelecidas entre a intensidade do impacto afetivo e a extensidade das coisas do mundo inteligivelmente dispostas, temos um encaminhamento próprio à orientação tensiva desenvolvida entre o texto-fonte e a charge. $\mathrm{O}$ quadro - em que o equilíbrio das figuras de cavaleiros vestidos com uniformes de gala favorece um olhar em extensão entre a amplidão do céu e a centralização do corpo de D. Pedro - projeta, para o gesto libertador e para a figura do Príncipe Regente tomado pela notável coragem, expectativas de um "acontecimento extraordinário", arrebatador, tal qual previsto semioticamente por Zilberberg (2011, p. 169), que define tal acontecimento como "figura do inesperado". No gesto condensado no grito "Independência ou Morte", que, segundo a narratividade subjacente, é o ápice da performance heroica do sujeito, estaria, segundo nos permitem pensar os desdobramentos tensivos da semiótica, a voz do ator 
do enunciado (o interlocutor), que, relatada em discurso direto, está imersa num "espaço tensivo" (ZILBERBERG, 2011, p. 169). Esse espaço cuida do impacto dos afetos sobre a compreensibilidade das coisas do mundo. Diz o semioticista:

0 acontecimento não poderia ser apreendido senão como algo afetante, perturbador, que suspende momentaneamente o curso do tempo. Mas nada nem ninguém conseguiria impedir que o tempo logo retome seu curso e que o acontecimento entre pouco a pouco nas vias da potencialização, isto é, primeiramente, na memória, depois, com o tempo, na história, de maneira que, grosso modo, tal acontecimento ganhe em legibilidade, em inteligibilidade, o que perde paulatinamente em agudeza (ZILBERBERG, 2011, p. 169).

Vincular a voz dos actantes ao "espaço tensivo" contribui para que se depreenda o corpo como presença. Voltando à obra de arte, vemos que ela oferece, segundo a agudeza estética, a centralidade do acontecimento, como diz Zilberberg, a cada vez que é contemplada. Ela vai ao encontro da intensidade dos afetos como princípio de maximização da estesia, conforme estudos já realizados (DISCINI, 2015b). De outro lado, a charge, como tom ou estilo do gênero, ganha em extensidade, enquanto a intensidade dos afetos tende a declinar com o humor. A charge de Kibeloco e o próprio exercício da performance blogueira, orientados pela bricolagem feita a partir de "Independência ou Morte", retiram, do gesto emparelhado ao Grito, a agudeza de "acontecimento extraordinário" para que tome lugar a crítica social cravada no humor, este que refaz a rotina das coisas do mundo. Enunciado e enunciação reconduzem então o gesto de interlocução, "Bora pra praia" (entre os outros de tais charges), ao tempo da história cotidiana, estabelecida nas relações ordinárias do dia-a-dia. Para isso, tra- 
tam a inteligibilidade do mundo sob as coerções do efeito de humor, que cobra distanciamento emocional.

Desse modo, as expectativas de acontecimento extraordinário são negadas pelo humor tendente à derrisão. Enquanto os cavaleiros, sujeitos adjuvantes da performance heroica de D. Pedro, acenam todos com chapéus e lenços para o alto; enquanto a topologia das figuras, ao juntar cavaleiros e cavalos em gesto de bravura, privilegia os altos como retenção desejável para nosso olhar; enquanto se homologa aos altos eufóricos o conceito de destino vitorioso de uma nação libertada de Portugal, o quadro passa a acolher a charge, e esta, aquele. Mas o ambiente semântico do quadro é subvertido. Para isso favorece a metamorfose dos atores, do espaço e do tempo, no movimento que contempla a co-presença. Configurada sob um efeito de inadequação, a co-presença se emparelha ao efeito de irreverência, decorrentes, ambos os efeitos, dos balões de fala inseridos pelo chargista. Assim se firma o rumo da sátira social. Enquanto isso, toma corpo o Kibeloco. Na dimensão semântica e na dimensão tensiva se encarna semanticamente o corpo de tal blogueiro, que, afeito à zombaria, ao produzir seu blog, aproxima-o de certa "verossimilhança realista" (BAKHTIN, 1987, p. 210) sem assumi-la por completo. Afinal, os atores, as datas e o ambiente semântico dessas charges existem como fatores de nossa História. Essa proximidade com uma "verossimilhança realista" é uma entre outras condições de produção do sentido próprias ao gênero. Segue outra frase contida pelos balões que encerram o grito de D. Pedro: "Volta que deu merda!". 


\section{O corpo, a voz e o tom da voz}

Novas e diversas postagens reiteram o corpo, a voz e o tom de voz, como o estilo de Kibeloco. Em acesso feito por nós no dia 16 de dezembro de 2015, entre exemplares de fotomontagem como "História de Pescador (2)", “Banana”, aparece o título "Meia Entrada", que ancora postagem feita no dia 08 de setembro de 2015. Em meio à série dos posts desse dia está então o vídeo que diz respeito à notícia veiculada em dias anteriores à edição considerada do blog. É notícia sobre um anão que teria sido contratado como gogo-boy para participar de uma festa numa repartição pública do Estado de São Paulo. Eis um desdobramento da notícia: "O governador Geraldo Alckmin (PSDB) afirmou nesta terça-feira (8) que a Secretaria da Segurança Pública de São Paulo abriu investigação sobre confraternização realizada no Departamento Estadual de Prevenção e Repressão ao Narcotráfico (Denarc) que contou com a participação de um anão gogo boy."10 Kibeloco reproduz o vídeo, que teria sido feito por um dos convidados à festa, informação esta que também consta da reportagem citada: "[o vídeo foi gravado] por um dos convidados com câmera de celular e está circulando pelas redes sociais. A reportagem do G1 teve acesso ao vídeo em que o anão aparece tirando a roupa, subindo em uma mesa, depois pulando de cueca da mesa, sentando no colo de uma mulher e depois no colo de um homem".

No blog, imediatamente abaixo da cena que dá abertura para assistirmos ao vídeo, há este comentário postado à moda de pergunta retórica: "O que faz um anão contratado como gogo-boy dentro do Departamento de Narcóticos (DENARC)? Pois é. Nós, o secretário estadual de Segurança Pública e a

10 Disponível em: 〈http://g1.globo.com/sao-paulo/noticia/2015/09/〉. Acesso em 16 dez. 2015. 
Corregedoria também não fazem ideia." ${ }^{11} \mathrm{Na}$ importação feita do vídeo firma-se a transversalidade como orientação imprimida no modo de produção do sentido. Mediante a práxis enunciativa trazida à luz pelo blog, a qual supõe a recorrência de atualizações, confirma-se a sistematização do uso feito do discurso do outro como princípio ditado por um regime que "pede o concurso da mistura e da abertura, tendo por benefício a expansão" (FONTANILLE; ZILBERBERG, 2001, p. 47). Entre outros, este é um vetor do estilo do gênero (DISCINI, 2015b): a preferência por "um modo [misturado] de existência do valor" (FONTANILLE; ZILBERBERG, 2001, p. 59) - a preferência, portanto, por uma valência que faz prevalecer a mistura sobre a triagem. Ao interagir com esse vetor do estilo do gênero, Kibeloco dá encaminhamento próprio a seu estilo de fazer blog de humor.

A mistura é legitimada pelo humor, que, em princípio, é da ordem do movimento grotesco, como nos ajuda a pensar Bakthin (1987). 0 filósofo e teórico da linguagem, ao estudar a cultura carnavalesca na Idade Média e no Renascimento, afirma: "O princípio cômico que preside aos ritos do carnaval, liberta-os de qualquer dogmatismo religioso ou eclesiástico, do misticismo, da piedade" (p. 6). 0 pensador russo destaca então que tais ritos "não pedem nem exigem nada" (p. 6).

Se, nas charges levadas a cabo no blog há uma ambiguidade própria ao humor, há também nelas uma sombra, tênue, embora de um riso carnavalesco. Mas essa sombra tende a dissipar-se no movimento de construção do sentido próprio à sátira, caracterizada como crítica com alvo certeiro e como o que cobra julgamento moral e posicionamento na instância da enunciação. A acepção dicionarizada de sátira já aponta

11 Disponível em: 〈http://www.kibeloco.com.br/page/3/〉. Acesso em: 16 dez. 2015. 
para seu caráter sancionador, ao registrar para ela o sentido de censura espirituosa (HOUAISS, 2009). Desse modo, acaba por mover-se alternadamente entre uma mistura e uma triagem de valores o corpo do blogueiro Kibeloco - na alternância, o ritmo que funda a voz e o tom da voz autoral. Mas o estilo do gênero, que respalda o estilo autoral, mantém-se na dominância da mistura sobre a triagem devido ao formato que favorece a expansão participativa entre internautas.

Sempre ladeada por comandos como "Comente", que convidam o leitor a clicar e entrar, e pelo desenho de um balão de fala vazio, que também oferece um convite para clicar, entrar e emitir opiniões, a página do blog mantém, como regularidade discursiva, a isotopia da difusão actorial. A presença regida por valores de universo já se esboça na textualização por meio de outras convocações que funcionam como rubricas abertas aos cliques: "Envie conteúdo". "Envie uma notícia". Assim, no encadeamento de um mundo recortado de modo próprio, prossegue o discurso do blog, enquanto fica projetada a imagem do ator da enunciação, esse Kibeloco delineado semanticamente como um corpo debochado. Em estudo anterior sobre charges, encontramos essa afirmação: "Na charge, o corpo debochado, construído no enunciado, remete [...] ao modo de ser do ator da enunciação" (DISCINI, 2015a, p. 176). No humor de Kibeloco, projeta-se um princípio de ambiguidade, aliada dos valores de mistura, estes para os quais tende a presença no âmbito da internet.

Ao depararmo-nos com o discurso na internet, ficamos postados diante de um corpo que - calcado num efeito discursivo de identidade previsto pelas circunstâncias da Webconfigura a presença inclinada a orientar-se pelos recursos de interface, afins com a perspectiva para a qual "a 'importância dos valores é função de sua extensão", como dizem Fontanille 
e Zilberberg (2001, p. 49). Fica robustecida a presença regida por valores de universo, que supõem "a predominância da [...] abertura sobre o fechamento e a predominância da [...] da mistura sobre a triagem", segundo os mesmos semioticistas no estudo citado (p. 53). Essa presença se comprova na prática contínua de inserção de posts e de atualizações, além da interactorialidade comprovada. Kibeloco se emparelha: ao comentador; ao sujeito que fez o vídeo incorporado; à mídia que noticiou o fato veiculado pelo vídeo; ao enunciador do quadro que serviu de base para suas bricolagens, e assim por diante. Como efeito de sentido do discurso firma-se o segundo dilúvio e a explosão anárquica de informações, para que tome corpo o estilo Kibeloco a partir da relação estabelecida com o estilo do gênero. É um corpo fluido, porque atrelado à fluidez do suporte - considerado este na acepção de configuração material própria à textualização. É um corpo fluido também devido à impregnação do sentido ambivalente, próprio ao princípio cômico. 0 sarcasmo, entretanto, quando fortalecido, opera na contramão dessa fluidez, fazendo alternarem-se as preferências: no lugar da mistura faz valer a triagem. Na alternância com intervalos regulares, está o ritmo.

O sarcasmo pode ser fortalecido a cada figura selecionada pelo blogueiro, em consonância com postagens e comentários que lhe enviam seus sujeitos adjuvantes e até seus oponentes. Para o vídeo do anão, por exemplo, o título é Meia Entrada - o que aponta para a pejoração vinda do ator blogueiro para o tamanho do anão. Mas a pejoração atinge toda a sequência de cenas enunciadas, e, mediante o comentário imediatamente colado ao vídeo, dirige-se ao descaso da administração pública e à desarticulação moral dos funcionários envolvidos. Aliada à sátira, a pejoração contribui para que se componha um humor aspectualizado telicamente. Há um té- 
los, um fim necessário a ser atingindo pela ironia cáustica: um fim, sem o qual o processo de construção do sentido não se cumpre. Essa telicidade na construção do humor fortemente destinado à crítica social acaba por aspectualizar o corpo do ator da enunciação, o Kibeloco, também como télico, conforme estudo feito sobre a aspectualização da pessoa discursiva (DISCINI, 2015b). Aliado à pejoração, contígua do sarcasmo, oscila o corpo segundo um ponto de vista inclinado ao "empobrecimento em extensidade", que, como dizem Fontanille e Zilberberg ao interrogar o próprio valor (2001, p. 59), levaria o corpo a adotar um princípio de exclusão como modo de existência. Mas move-se alternadamente o corpo de Kibeloco, entre a exclusão própria à sátira e a participação constitutiva do gênero digital, polo este afinado com a biisotopia semântica em que se aninham as charges.

Afirmam Fontanille e Zilberberg (2001, p. 59) que "a pejoração é antecâmara da exclusão, assim como a denegação da pejoração, quando intervém, permite prever uma reintegração próxima daquele que era ameaçado de exclusão". No blog do Kibeloco, a sátira social imprime no discurso a orientação de pejoração e exclusão, mas a ambiguidade é retomada. Atrelado à intencionalidade humorística do blog, aliado à expansão participativa própria à prática blogueira, o discurso é recolocado junto aos enunciados que promovem a reintegração do que é "excluído". Assim o blog é devolvido ao seu lugar primordial, que é o regime da mistura na valoração dos valores.

Lembramos outra postagem feita no dia 08 de setembro de 2015, apresentada sob o título "Vergonha Alheia. Records (Parte 181)". Essa postagem se mantinha na janela "Posts mais antigos" - janela que se mantém e que se abre a um clique na diagramação de finalização da página no mesmo site citado do kibeloco. Nesse dia, aparece o vídeo de Osmarzinho, 
que canta "Menina me dá o Loló" - refrão repetido indefinidamente ao longo de todo o vídeo ${ }^{12}$. Entre uma visualidade monótona, viabilizada plasticamente por uma tela de TV ao fundo, Osmarzinho, em pé, toca violão em gestualidade rígida. Junto da melodia monocórdica e diante do ator Osmarzinho, que usa óculos escuros e roupa preta, configura-se o apelo sexual como argumento central da cena. A tematização e a figurativização próprias à letra da canção, junto à demanda suplicante ("me dá o Loló"), são banalizadas pela repetição prolongada do refrão, que, visualmente, passa a ancorar uma nova isotopia. Aparece então a figura do Loló, ao entrar em cena um cachorro branco de pelúcia. Mas a biisotopia não funda a ambiguidade do humor, tamanho é o direcionamento unilateral para o conteúdo sexual. 0 corpo enrijecido de Osmarzinho se confirma na "degeneração do princípio cômico" (BAKHTIN, 1987, p. 34) no interior do vídeo importado e no tratamento ético oferecido ao vídeo pelo blogueiro, como de absoluta pejoração. Ao vir postado junto ao título, "Vergonha Alheia", fica fortalecida no Kibeloco a voz de crítica social com o tom maledicente e a ironia sarcástica. Abaixo da imagem reproduzida como janela para o vídeo que se abre ao toque, há convites como "Compartilhe, Link para o Twitter", "Link para o google", (embora seja necessária uma senha para tweetar e para dar prosseguimento no google). Mas a pejoração era acionada por contágio já nos comentários. Entre as postagens de comentários reproduzidas no blog havia esta: "Vou dormir com essa merda na cabeça".

12 Vídeo publicado em 26 de agosto de 2015; artista: Osmarzinho; música: Menina me dá o Loló; participação especial: Luiz Carlos (como Loló). Disponível em: 〈https://www.youtube.com/watch?v=sRZh8TKmf_s». Acesso em: 15 dez. 2015 


\section{Blog, TV e fotomontagem: a transversalidade}

Entre os chamados "posts mais antigos" do Kibeloco encontramos ainda este, "Quero Sílvio" (de 03/ 09/ 2015), vídeo televisivo de programa de auditório, em que, em meio a risadas coletivas da plateia, toma lugar central na cena um cartaz empunhado por uma interlocutora de Sílvio, que ele chama de Tatiana. Mas, antes da interlocução, a moça do auditório permanece em pé, em frente a uma fila, no aguardo do encontro com Sílvio Santos, o animador. 0 cartaz manuscrito traz estes dizeres, que Sílvio lê como se estranhasse o sentido: "Se um quero-quero cruzar/ com um pica-pau, que/ nome eles deveriam/ colocar na filha deles?" Depois Sílvio passa a perguntar: "É boa, essa [quadrinha]?" Então o animador, que confessa nunca ter ouvido falar em quero-quero (pássaro de regiões campestres do Brasil), insiste com o auditório no processo linguístico que resultaria em algum nome para a filha do quero-quero e do pica-pau: "Quero pau/ Quero pica/ Quero pica-pau”. 0 auditório, composto por mulheres de várias idades, bate palmas e ri. Sílvio completa: "É boa, parece música de carnaval" - e dá cem reais para Tatiana ${ }^{13}$. A postagem adquire ares provocativos por meio da pergunta subentendida à afirmação, que sucede a cena de abertura do vídeo como postagem. A afirmação é: "Volta e meia Silvio Santos nos lembra por que virou um mito". A provocação subentendida é: Sílvio Santos virou (é) verdadeiramente um mito? Muitos comentários se alinharam a tal provocação.

Por conseguinte, no interior do mesmo blog, a transversalidade apresentada entre as postagens relativas a determinado dia remete, também, às vozes de produtores de vídeos, que po-

13 Disponível em: ‘http://www.kibeloco.com.br/page/6/〉. Acesso em: 15 dez. 2015. Vídeo publicado em 31 de agosto de 2015: Sílvio Santos, em Quero pica e Quero pau. Disponível em: 〈https://www.youtube.com/watch?v=caCAvenb2EM〉. Acesso em: 15 dez. 2015. 
dem vir de outras mídias como a TV. Assim, o blogueiro se apresenta como um sujeito competentemente firmado na mediação contínua. Ele quer e sabe blogar, o que convoca, juntamente com o poder de acesso à tecnologia digital, o gosto pela interatividade estendida sob o efeito de sentido de multiplicação actorial ad infinitum, o que é favorecido pelo aparato material da Web. No blog Kibeloco, no dia 03 de setembro de 2015, como consta do cabeçalho da edição consultada, Kibeloco - ao postar, juntamente com a imagem (que serve de porta de entrada para a visualização a ser feita do vídeo), a cena do programa de auditório Sílvio Santos (SBT) e, no que seria chamado no âmbito do jornalismo tradicional como lide, ao postar esta frase: "Volta e meia Sílvio Santos nos lembra por que virou um mito"14 - favorece o subtendido da pergunta retórica, viabilizando o querer, o poder e o saber que antecedem o ato de participação efetiva do sujeito que intervém no blog como comentador.

Figura 3 - Imagem que dá entrada ao vídeo do programa de auditório de Sílvio Santos

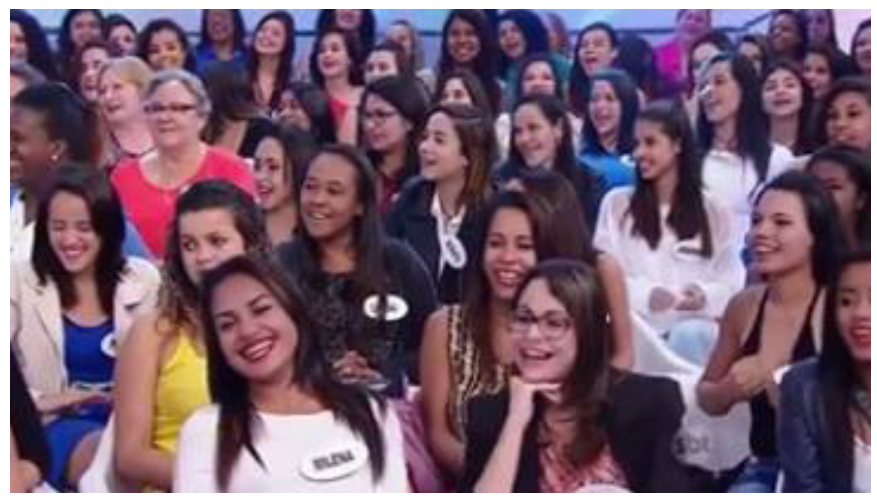

Fonte: Blog Kibeloco

14 Disponível em: https://www.facebook.com/KibeLoco/videos/10153641132004470/>. Acesso em: 16 dez. 2015. 
0 vídeo disponibilizado, quando aberto, traz o animador adentrado em meio à pequena multidão de mulheres sentadas, que, bem-humoradas, respondem em coro e obedientemente aos comandos de Sílvio. Em meio à descontração ostentada, a moça, Tatiana, a primeira da fila de aguardo, apresenta o cartaz manuscrito com a narrativa do acasalamento entre os dois pássaros. De acordo com o princípio da ambiguidade na construção do sentido próprio ao humor, percebemos que não importa se é verdadeiro o estranhamento inicial do animador em relação aos dizeres do cartaz: não importa se é verdadeiro (parece e é estranhamento) ou mentiroso (parece estranhamento, mas não é; é interpretação teatral). Aparentemente vale rir à toa. Então Sílvio repete, primeiro sozinho, depois com o auditório, e em cadência rítmica, o que seria o processo de construção linguística do nome da filha das aves. No refrão animado, precedido de uma espécie de soluço (relativo a um presumível susto) de Sílvio, é repetido três vezes cada um daqueles segmentos textuais - "Quero pau/ Quero pica” - que preparam o último, quero pica-pau. Silvio ri com vontade, no modo do parecer pelo menos. Seguem alguns comentários postados, acompanhados por um espaço em branco, onde o internauta pode colocar uma resposta àquilo que escolher - para o que basta estar cadastrado no Facebook. Assim se contabilizam, com os comentários, curtidas e compartilhamentos. 
Figura 4 - Reprodução parcial da seção relativa a comentários sobre o vídeo do programa de Sílvio Santos

2.050 curtidas $\cdot 457$ comentários $\cdot 725$ compartilhamentos Emiliana Duarte, Guilherme CM, Daiane Oliveira e outras 2.049 pessoas curtiram isso.

726 compartilhamentos

Andre Bega 0 cara tem mais de 80 anos e consegue fazer umas 200 mulheres ficarem repetindo que querem pau... realmente é um mito

$112 \cdot 3$ de setembro às $10: 55$

6 Respostas

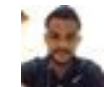

Nilson Da Silva Brites Silvio Santos é um mito conseguiu fazer a mulherada dizer que quer pica e só pagou pra uma!

$66 \cdot 3$ de setembro às $11: 16$

4 Respostas

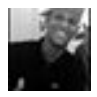

Edissandro Ribeiro Silvio Santos, incomparável mito!

$10 \cdot 3$ de setembro às 11:01

Ver mais comentários

Fonte: Blog Kibeloco 
Sígnica e discursivamente, o mundo está categorizado no enunciado do vídeo "Quero Silvio"; está também categorizado no blog, que, ao incorporar tal vídeo no seu interior, nomeia o mundo por meio da orientação imprimida pela montagem feita (na edição de 03 de setembro de 2015) a partir de um programa de TV, no mecanismo exaltador de interfaces favorecido pela internet: enunciado plural; enunciação plural. Tal nomeação feita de um mundo pluralizado potencializa o corpo enunciativo de Kibeloco como estilo autoral, enquanto ratifica como "memória esquemática" o estilo do gênero.

Sobre a potencialização relacionada a uma memória esquemática e à práxis enunciativa, afirmam Fontanille e Zilberberg (2001, p. 58): “a potencialização, principalmente pelo efeito da práxis enunciativa, conduz a um retorno das formas do uso para o sistema ou, pelo menos, a uma memória esquemática que fica em seu lugar". Uso, sistema, norma, memória esquemática: essas noções permeiam o conceito discursivo de estilo. Na perspectiva discursiva, o estilo é concebido não como um desvio (um a-mais do sentido), estabelecido em relação a uma norma ordinária da expressão. Tudo tem estilo.

Assim o estilo é concebido como um sistema, uma estrutura que subsidia uma totalidade de enunciados, bem como uma enunciação, que, advinda dessa totalidade, é configurada segundo um modo organizado e recorrente de dizer. 0 estilo se oferece à descrição por meio do exame feito de vetores estilísticos, colhidos lá, cá e acolá ao longo de uma totalidade discursiva. A partir daí, inevitavelmente chegamos ao blog e ao estilo do gênero.

No âmbito dos estudos discursivos, o estilo é pensado também como uma estrutura aberta, já que o enunciado e a enunciação são considerados na porosidade que os constitui em relação ao que é contíguo a eles e constitutivo deles - o 
outro - levado em conta como o ator cravado no interdiscurso. É a um sistema concomitantemente homogêneo, fechado em si, e heterogêneo, aberto ao mundo, que o conceito discursivo de estilo se refere. De tais ponderações, emerge o estilo do blog, fortemente definido na sua heterogeneidade constitutiva e como heterogeneidade mostrada (AUTHIER-REVUZ, 1982). Ao importar para si e mostrar em si um programa de auditório da TV, o blog faz um exercício de heterogeneidade mostrada.

O gesto de importar e mostrar o que importa é um vetor estilístico do gênero, confirmado no estilo autoral. Da recorrência de um modo de dizer, o ator discursivo, o blogueiro Kibeloco, desponta como estilo autoral. No exercício de suas escolhas, apresenta-se o ator conforme uma práxis enunciativa que faz retornar "as formas de uso para o sistema", na projeção discursiva de uma "memória esquemática", que funda determinado campo de presença. Nessa "memória esquemática" está também a inclinação à sátira. Assim entendemos o gesto de Kibeloco de postar aquela cena que é janela para o vídeo "Quero Sílvio", encadeada à cena-janela do vídeo "Menina me dá o Loló"; e, no encadeamento entre as postagens, esta foto, que segue reproduzida. É outra fotomontagem, base de outra charge, que confirma a inclinação à pejoração como crítica social ${ }^{15}$.

15 Disponível em: 〈http://www.kibeloco.com.br/page/3/〉. Acesso em: 16 dez. 2015. 
Figura 5 - Fotomontagem feita a partir de fotografia veiculada na mídia por ocasião da comemoração da Independência do Brasil

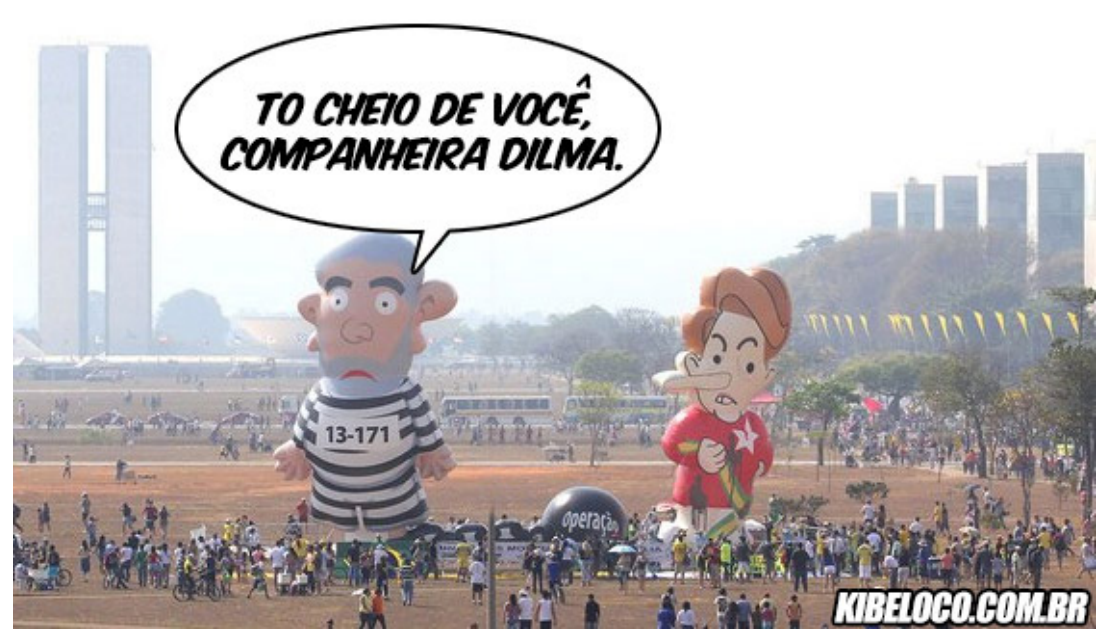

Fonte: Blog Kibeloco

Essa fotomontagem foi postada no dia 07 de setembro de 2015 no blog Kibeloco. Sob o título "Pixulecando", em retomada temática, figurativa e textual de notícias relativas à operação Lava-Jato, segundo as quais propinas são investigadas em relação a escândalos de corrupção na Petrobrás, o blogueiro toca de leve no que seria um resíduo contemporâneo do "grotesco da Idade Média e do Renascimento" (BAKHTIN, 1987, p. 41). 0 grotesco "impregnado da visão carnavalesca do mundo, libera este último de tudo que nele pode haver de terrível e atemorizador, torna-o totalmente inofensivo, alegre e luminoso" - segundo o pensador russo (p. 41). Os bonecos infláveis, fato do mundo noticiado, apontam de alguma maneira para uma visão carnavalesca, mas da contemporaneidade. Eles nos poupam por um momento de alguma ameaça trazida 
pelos relatos de desconcerto político e de reveses econômicos, encerrados na rubrica que se repete ao longo das edições do jornal Folha de S. Paulo: Brasil em crise. A montagem da charge aumenta a tendência carnavalesca contemporânea, ao brincar com informações relativas à sequência da rubrica "Brasil em crise". 0 interdiscurso circunda e atravessa o texto humorístico também por meio de notícias como esta, que traz à luz o ex-presidente Lula: "PF pede autorização ao STF para ouvir Lula na Lava Jato" (FSP, 12 de setembro de 2015, p. A4); também por meio de comentários como este, feito em crônica política, que discorre sobre a iminência do aumento de impostos cogitado pelo governo de Dilma. O colunista, relacionando tal aumento com promessas não cumpridas feitas na campanha para a eleição presidencial (2014), afirma: “Tentando restaurar a CPMF [...] [Dilma] apelou à mentira, sua companheira de cama e mesa" - coluna de Demétrio Magnoli, intitulada "As palavras no muro" (FSP, 12 de setembro de 2015, p. A10). A boneca inflável é figura alusiva a Pinóquio.

Por meio da charge, o blog se movimenta para a fronteira entre um efeito de ficção (a fala de Lula, tal qual criada pelo chargista) e um efeito de não-ficção, a foto dos dois bonecos infláveis veiculada na mídia por ocasião das festividades de aniversário de nossa Independência. "Pixulecando", o título da postagem, garante a volta à realidade discursivizada como notícia jornalística, já que as ditas propinas foram chamadas de "pixuleco" ao longo da Operação Lava-Jato. Em recuperação da mídia impressa, a explicação sobre a foto, que é o texto-fonte da montagem, aparece deste modo - o que no original está em vermelho e se apresenta aqui grifado é, na página da internet, janela aberta para a navegação expandida:

Manifestantes contrários ao governo levaram na manhã desta segunda-feira (7) para a Esplanada dos Ministérios, 
em Brasília, bonecos infláveis representando o ex-presidente Luiz Inácio Lula da Silva - com roupa listrada, de presidiário - e a presidente Dilma Rousseff. Os bonecos foram exibidos simultaneamente ao desfile oficial do 7 de Setembro, do qual Dilma e ministros participavam ${ }^{16}$.

Figura 6 - Fotos dos bonecos infláveis veiculada na mídia impressa e em reprodução on-line por ocasião das comemorações da Independência do Brasil ${ }^{17}$

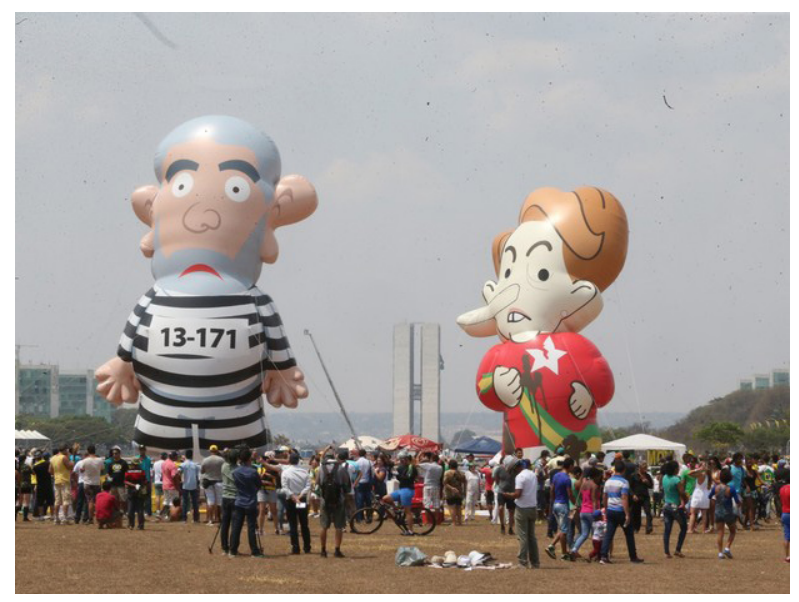

Fonte: Blog Kibeloco

0 "Brasil em crise" certamente não alija os brasileiros do sentimento de ameaça e, com essa percepção, não estamos blindados em relação a incertezas relativas ao destino do país; com as incertezas, abre-se caminho para algum temor em re-

16 Disponível em: 〈http://g1.globo.com/distrito-federal/noticia/2015/09/manifestantes-levam-bonecos-de-lula-e-dilma-para-brasilia-durante-desfile.html. Acesso em 16 dez. 2015 .

17 Disponível em: 〈http://g1.globo.com/distrito-federal/noticia/2015/09/manifestantes-levam-bonecos-de-lula-e-dilma-para-brasilia-durante-desfile.html. Acesso em: 16 dez. 2015. 
lação ao que possa vir a acontecer. Então, já na historicidade da charge, temos um afastamento em relação ao grotesco trazido à luz por Bakhtin (1987, p. 41), que afirma: "0 medo é a expressão extrema de uma seriedade unilateral e estúpida que no carnaval é vencida pelo riso. [...] A liberdade absoluta que caracteriza o grotesco não seria possível num mundo dominado pelo medo". Admitindo certa apreensão no momento histórico vivido nesses dias pelo brasileiro, e admitindo que a charge (no enunciado e na enunciação) procura discursivizar essa apreensão, subvertendo-a comicamente, vemos a pejoração voltar à luz na voz do ex-presidente Lula: "Tô cheio de você, companheira Dilma".

Na pejoração, despontada novamente, firma-se no blog Kibeloco um princípio de distanciamento em relação ao riso regenerador próprio à visão carnavalesca estudada por Bakhtin na cultura popular da Idade Média e no Renascimento. Tal distanciamento é favorecido por muitos traços da semântica discursiva. Entre esses traços está o direcionamento próprio ao sarcasmo e à sátira processados no interior das charges e no modo de tratar os vídeos incorporados. 0 distanciamento referido também está no apelo mercadológico centrado na rubrica "Anuncie"; está, por fim, no dever ser segundo os parâmetros da difusão midiática, a qual acaba por engessar o corpo na estereotipia dos movimentos previstos, cravados na interface obrigatória da comunicação digital.

\section{Semiose e campo de presença}

Procurar entender o blog como discurso e sob a perspectiva de uma semiótica de raiz greimasiana (GREIMAS; COURTÉS, 2008) cobra uma postura teórica e metodológica: 
pensar cada texto que compõe a totalidade genérica blog, segundo a função semiótica. Essa função estrutura cada um dos textos que o blog encerra (e encerra textos - num plural a ser expandido devido às aberturas oferecidas por links e à possibilidade de inserção de comentários-postagens etc.). A função semiótica também compõe determinada edição do blog, segundo um texto apresentado como um todo de sentido, assim flagrado no exame que se pode fazer de uma postagem geral e acabada, relativa a determinado dia, hora, mês e ano do mesmo blog. A leitura não afeita a prosseguir na participação que se oferece em desdobramentos múltiplos pode congelar a página da Web correspondente ao blog.

Se levarmos em conta determinada edição do blog, acessada pelo usuário da internet com o fim específico de ler aquela página sem expandi-la com comentários e novas postagens, virá à luz a unicidade que respalda o corpo do blogueiro como uma presença dada na ordem da "realização" (FONTANILLE; ZILBERBERG, 2001, p. 58). Aquela edição, que é única e que pode ser arquivada e imprimida pelo analista, congelada pela leitura crítica, portanto, permite que se examine o blogueiro como um sujeito imobilizado, em conjunção com o mundo discursivizado. Mas, simultaneamente, o blogueiro que assina o blog apresenta-se como identidade móvel, já que, a partir dos mecanismos de construção do sentido firmados no discurso, desponta o ator instituído na interação explícita, "mostrada", com seus pares. 0 ator concernente à esfera $W e b$ da comunicação e ao gênero blog - ainda que preso ao recurso metodológico de uma análise que o contempla como efeito de sentido colhido numa única edição (presença realizada) - torna relevante, para a definição da própria identidade, a complementaridade entre a realização e a atualização. Mais que isso, pende para a última. A identidade blogueira se 
define como presença atualizada. É condição de existência da presença a interação "mostrada", levada a cabo no interior da página da Web. Então, mesmo congelado por uma leitura não dada a invadir a página, o blogueiro, como "um modo próprio de dizer que funda um modo próprio de ser no mundo" - segundo definição discursiva de estilo (DISCINI, 2015a) só é uno porque é múltiplo.

Assim podemos admitir que o estilo blogueiro, necessariamente remetido à presença atualizada, processada na antessala da realização, firma-se orientado pela falta. 0 blog exacerba o princípio de que não levamos em conta, nos estudos feitos sobre a linguagem e o discurso, a coisa em si, pois se firma segundo o modo de dizer que prioriza a atualização na relação estabelecida com a realização - da presença. Fontanille e Zilberberg (2001, p. 58), de cujo pensamento extraímos noções que fundamentam o conceito de presença, lembram que "a acepção linguística mais corrente da atualização é a de uma 'subida' das estruturas virtuais em direção à manifestação e, por conseguinte, em direção à realização".

Ao não nos restringirmos ao artificial congelamento de imagem feito pelo analista, acabamos por ter à mão, como possibilidades abertas para o acolhimento de novos enunciados, também espaços em branco, mantidos para ser preenchidos com respostas aos comentários e outras intervenções na própria diagramação do blog. Esses espaços nos levam a querer inserir postagens e nos oferecem recursos para poder fazê-lo. São espaços que, juntamente com a abertura sugerida para novas atualizações e novos comentários, mantêm-se no aguardo de novas inserções, materializando condições de emergência dos valores de universo no modo como nosso corpo se põe diante da práxis enunciativa que se nos oferece como opção de comunicação. Logo, na própria textualiza- 
ção, considerada no processamento da diagramação do blog, configuram-se esses espaços-pausa, aliados a um regime de presença que, firmado na oposição entre "o uno e o numeroso" (FONTANILLE; ZILBERBERG, 2001, p. 136), privilegia o segundo termo.

Pausa remete à noção tensiva de parada. Tatit (2002, p. 201) faz uma "representação [...] operacional" de valores vinculados a um processo que supõe, na sintaxe das profundidades tensivas, uma distribuição entre paradas e continuações:

Esquema 1 - Reprodução de quadrado representativo de relação sintáxica estabelecida entre valores tensivos

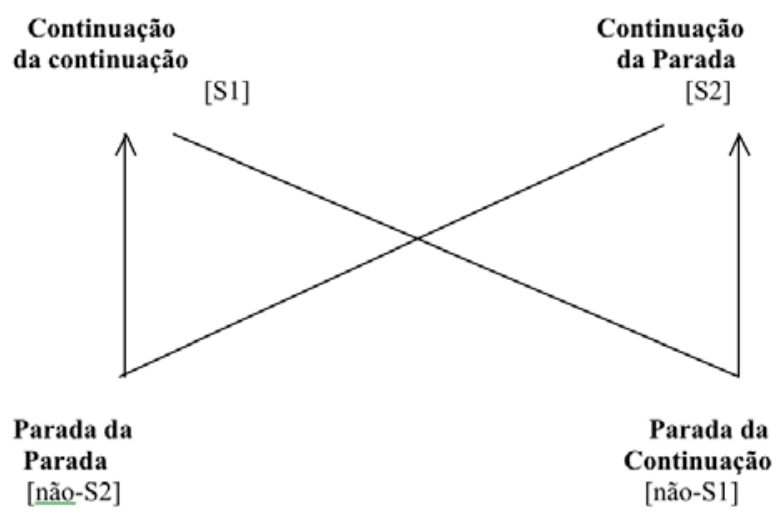

Fonte: Tatit, 2002, p. 201 - com inserção didática da nomeação dos termos como S1; S2; não-S2; não-S1, feita por nós a partir da noção de quadrado semiótico (GREIMAS; COURTÉS, 2008).

Podemos trazer tais encadeamentos sintáxicos para o exame do campo de presença no blog. Entendemos que, conforme uma parada (não-S1) - que condiciona na textualização a irrupção do link e das intervenções - esses espaços de pausa permitem entrar o "turno da fala" do internauta que está por 
vir, num efeito ou simulacro de comunicação ao vivo. A parada (não-S1) na textualização e no discurso, sugerida pela irrupção de um link e pela diagramação que favorece os espaços em branco acolhedores de comentários, mantém-se em continuação (continuação da parada, S2), enquanto dura o exercício de fazer as inserções. Evolui em seguida na direção de uma parada da parada (não-S2), que sustenta, em complementaridade, a continuação (S1) do corpo do blogueiro: esse corpo que, inclinado a ser regido pelos valores de universo, como um modo de ser, logo afeito a assumir a mistura de valores, adapta-se melhor ao movimento que supõe a parada da parada.

Assim a continuidade das postagens respalda o corpo móvel, cujo modo de existência é a falta, articulada à atualização contínua (do enunciado e da enunciação). A enunciação em ato, como práxis enunciativa que contempla a expansão participativa do outro internauta, está nesse polo de presença atualizada - um sujeito "mobilizado", no entender de Fontanille e Zilberberg (2001, p. 144). Para a configuração dessa presença mobilizada contribuem os tais espaços em branco, que, na materialidade da diagramação do blog, são preenchíveis por respostas a ser dadas aos comentários, bem como por outras e variadas inserções (a depender do formato do blog). 0 blog do Kibeloco, autointitulado como um "site de entretenimento" o comprova ${ }^{18}$.

Os dois semioticistas citados, ao discorrer sobre o que é a "presença", falam de uma "tipologia de sujeitos", para o que consideram a presença realizada, estabelecida na ordem da "plenitude" e a presença atualizada, estabelecida na ordem da "falta" (2001, p. 134). Em seguida, homologam o realizado ao "uno" e o atualizado ao "massivo" (p. 136). Entendemos que a

18 Disponível em: ‘https://www.facebook.com/KibeLoco/videos/10153641132004470/〉. Acesso em 16 dez. 2015. 
presença nos blogs e nos gêneros afins ancora-se na ordem do massivo, o que é exposto pelos mesmos semioticistas como "grupos indissociáveis, massas pouco articuladas, porém individualizadas" (p. 137). São indissociáveis, as massas de participantes, já que convergem para e pela intencionalidade do blog, mas são de uma interconexão não definitivamente encerrada em seus limites, devido ao aspecto incoativo que caracteriza o movimento das postagens e atualizações. A presença realizada diz respeito, portanto, à página congelada artificialmente, o que supõe o blogueiro como corpo definido dentro dos limites de uma única edição acessada. Essa presença comporta um enunciador em conjunção com o enunciado congelado - pontual e artificialmente - pelo leitor ou pelo analista. É um corpo, ainda, sensivelmente posto segundo certo "relaxamento", como aponta Tatit (2002, p. 200) no mesmo estudo, que recupera o pensamento de Zilberberg (2006) sobre orientações emissivas e remissivas do sensível na percepção de mundo.

Ao procurar entender o blogueiro como campo de presença, constatamos que não se incompatibilizam os pontos de vista de Zilberberg (2006) juntos ao de Tatit (2002), de um lado, e, de outro, o pensamento de Fontanille e Zilberberg (2001). Verificamos isso ao comprovar que, ancorado na falta, que precede a realização, firma-se o blogueiro também como um corpo distenso. Para ser móvel e por ser móvel, ancora-se esse corpo na parada da parada (polo não-S2 do quadrado) lugar de articulação que o blogueiro "em ato" dá a entender como modo seu na percepção de mundo. Segue reprodução do quadrado registrado por Tatit, a partir dos desdobramentos tensivos da semiótica feitos por Zilberberg (2006): 
Esquema 2 - Reprodução do quadrado de relações sintáxicas estabelecidas pelos valores tensivos articulados pela categoria fórica

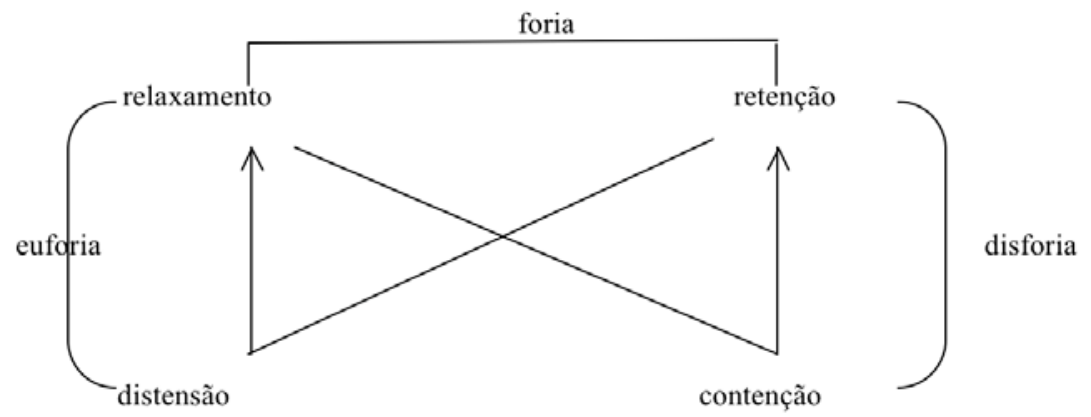

Fonte: (TATIT, 2002, p. 200).

Se ficasse circunscrito a pejorações sérias, o corpo do blogueiro dar-se-ia bem no polo da retenção. Mas o humor o conduz para a distensão. É o que nos levam a pensar as reflexões feitas sobre essa "força que transporta as categorias semânticas" (TATIT, 2002, p. 199), que é a acepção da noção de foria elucidada por Tatit: foria como força que desponta da relação estabelecida entre rupturas e continuidades encadeadas na movimentação sintáxica que respalda ainda as pré-condições da geração do sentido. A parada da parada, como elucidada por Tatit (p. 201) remete, no âmbito do blog, àquele sujeito de presença mobilizada ou a um sujeito em falta, esta constituída em relação de complementaridade com própria realização. Certamente é essa presença em falta, distensa segundo as modulações tensivas, mas ainda não relaxada, a dominante na definição do blogueiro como campo de presença.

Se procurarmos a dominância, que pode caracterizar o modo de presença do blogueiro, despontará o fato de que, entre a presença realizada (que supõe o blogueiro como corpo de- 
finido dentro dos limites de determinada edição - um enunciador em conjunção com o enunciado congelado artificialmente pelo analista) e a presença atualizada (que supõe o blogueiro como um corpo aberto, em falta, posto no intervalo entre uma postagem e outra), domina o último, visto o blog segundo a enunciação em ato. 0 modo de presença do blogueiro define-se no intervalo entre uma atualização e outra: corpo móvel, enunciado móvel, discurso orientado em princípio pelo regime da mistura, que acolhe valores de universo. É um corpo necessariamente aberto, porque contingente no jogo que se deflagra na interatividade "em ato" da comunicação on-line, esse corpo que pode subsidiar a página congelada artificialmente para a análise. Embora congelado por uma leitura de intervenção mínima, o corpo mantém-se definido no limiar com seu "exterior" - este último concebido como efeito de sentido. Mas é por meio de um congelamento da página que se define um meio de operacionalizar a descrição analítica de tal página da Web como um todo de sentido, tal qual encerrado em determinada edição de um blog. 0 congelamento metodológico não deixa, porém, de fazer escaparem as marcas enunciativas do sujeito mobilizado, já que o próprio congelamento analítico não é definitivo: sempre se intervém com participações, ainda que mínimas, ainda que não sejam efetuados comentários e outras contribuições para as atualizações.

Juntamente com esses modos de existência do blogueiro, entendemos que o blog se apresenta como uma totalidade de enunciados, que o compõe como "um enunciado relativamente estável" (BAKHTIN, 1997) ou um gênero digital, como diz Marcuschi (2010). A totalidade genérica ancora-se na estabilidade que diz respeito à construção composicional (o modo de organizar o texto), à temática (o domínio do sentido evocado) e ao estilo do blog - mantendo aqui por base o 
pensamento de Bakhtin sobre gênero (1997). A estabilidade, relativa, embora, mantém-se como organização composicional numa textualização que privilegia o hipertexto com o favorecimento aos links e que é introduzida invariavelmente por informações dêiticas - dia, mês da última atualização. Quanto ao desdobramento de vozes das instâncias enunciativas, conforme formalizado por Fiorin (1996), que realça, no nível discursivo, as relações entre enunciador e narrador no âmbito da enunciação enunciada, temos a organização composicional que favorece a regularidade com que diversos enunciadores-narradores tomam seu lugar no interior do discurso. Para isso contribui o suporte que, como materialidade da textualização, firma-se afeito a intervalar enunciados e enunciações distintos. Isso acontece seja por meio do favorecimento à performance sempre iminente relativa ao ato de comentar, de fazer postagens diversas, seja por meio da performance do produtor do blog prevista como inclinada a acolher atualizações contínuas. Essa orientação impregna a temática, já contagiada pela perspectiva voltada para "valores [...] participativos", que assumem a própria "relatividade", como sugerem Fontanille e Zilberberg (2001, p. 56).

No âmbito da temática do gênero, a estabilidade está no domínio midiático do sentido tal qual tratado pela Web. 0 tratamento mediatizado oferecido aos temas que entram na comunicação on-line processada num blog privilegia a difusão, já segundo a acepção dicionarizada do verbo mediatizar: difundir por meio dos veículos de comunicação (HOUAISS, 2009). A partir dessa difusão e juntamente com ela instala-se a expansão participativa dos atores internautas no interior de um blog.

No estilo do gênero, emerge o blogueiro responsável pelo blog como aquele sujeito que assina o blog e que, ao 
manter-se como presença mobilizada, firma o próprio corpo na ordem de uma falta atualizante. Enquanto isso sai favorecido o tom de difusão midiática, próprio à Web: um tom condicionado às circunstâncias de produção e manifestação do sentido, mas que se apresenta aliado de um simulacro segundo o qual as pessoas e os pronunciamentos feitos por elas são reais. Como simulacro, o tempo é real, o espaço é real - parecem não pautados pelas coerções da linguagem, do discurso e da esfera Web da comunicação.

Correlacionado à estrutura composicional e à configuração da temática, está o estilo, que, como presença firmada em corpo necessariamente mobilizado, projeta-se segundo um éthos discursivo que se dá a ver como contingente nessa "cena genérica” (MAINGUENEAU, 2006) da mídia on-line. Como um modo de dizer que pende para o privilégio oferecido à mistura e aos valores de universo, o que está radicado narrativamente na interactancialidade (na transversalidade entre os actantes encadeados por meio das postagens feitas), configura-se o blogueiro como um corpo inclinado a assumir funções de um actante coletivo: o uno, mostradamente múltiplo. Para isso, ancora-se o blogueiro na sequência de postagens feitas no interior do mesmo blog e num modo sistemático de dizer, reconhecível a partir do exame que pode ser feito de dois, três blogs de assinatura diferente - vistos cada qual como um ato de linguagem fundado na Web. Para isso também contribuem os modos de construção do humor, no que diz respeito ao estilo Kibeloco de fazer blog. Mas sempre estamos diante de um ato de linguagem, que supõe necessariamente a função semiótica. Ela marca os enunciados segundo o valor relacional do sentido.

Fundado no enunciado do blog, está o sujeito enunciador, que é encarnado semanticamente no papel temático de "mediador". Bertrand (2015, p. 7), ao discorrer sobre "me- 
diação e sentido negociado" refere-se ao papel temático específico do mediador como negociador. Sugere então que "o 'mediador' encarna particularmente essa função do papel temático" - para o que acrescenta que ele (o mediador) é aquele de quem a coletividade espera a garantia de "inserção de indivíduos ou de grupos de indivíduos" no interior de seu discurso. Bertrand completa que o mediador "é o fiador da sedimentação e da persistência dos actantes coletivos" (p. 7). A noção de actante coletivo certamente respalda o estilo do blog como corpo mobilizado. Mas, a partir do blog examinado, deduzimos que não é suficientemente consumado, na assinatura Kibeloco, o papel de um fiador definitivo da sedimentação do sentido: lá a cena enunciativa - o eu/ aqui/ agora da enunciação - apresenta-se difusa o suficiente para ser atenuada como sedimentação definitiva. Isso faz tomar força a cena genérica, embora dessa cena desponte o estilo Kibeloco de fazer humor. 0 estilo é, em princípio, diferencial (DISCINI, 2015a). É firmado na diferença o corpo de Kibeloco, diante daquele de outros blogs de humor, como o Não Salvo, que se apresenta segundo esta chamada: "Entre o céu e o créu existem coisas que você nem imagina”. ${ }^{19} \mathrm{~A}$ diferença se esboça aí já na temática.

Ao examinar os enunciados que compõem o Kibeloco somos remetidos ao blog como um objeto contemplado segundo sua função semiótica. Admitir com essa função a semiose constitutiva do blog é, segundo o viés teórico da semiótica, condição para que se examinem o processamento e a organização dos mecanismos de construção do sentido no interior dos enunciados que compõem o gênero. Estamos às voltas com um pensamento teórico, que, herdeiro de Saussure, trata o blog como signo, logo como uma unidade linguística

19 Disponível em: 〈http://www.naosalvo.com.br/〉. Acesso em: 16 dez. 2015. 
constituída de um significante e de um significado (SAUSSURE, 1970). Na retomada do pensamento de Saussure feita por Hjelmslev (2003), este que revê a relação entre significante e significado como a relação entre um plano da expressão e um plano do conteúdo (HJELMSLEV, 2003), deparamo-nos, diante do blog, com uma totalidade de textos fundante do gênero, cada texto entendido como um signo.

O plano da expressão e o plano do conteúdo encerram em si, cada qual a sua maneira, uma forma e uma substância, enquanto a semiose diz respeito à categoria sêmica que contempla a forma - como constituinte da expressão e do conteúdo. A forma concerne a uma rede de interdependências categoriais ou à estrutura que sustenta a substância. Esta (a substância) é o manifestante daquela (o manifestado, a estrutura). A análise semiótica, respaldada pelos princípios teóricos propostos por Saussure e Hjelmslev, permite pensarmos que um gênero da esfera midiática da comunicação on-line, como o blog, apoia-se num conjunto de textos, instaurado cada qual segundo "uma relação de pressuposição recíproca entre a forma da expressão e a do conteúdo (na terminologia de L. Hjelmslev) ou entre o significante e o significado (F. de Saussure)" - como sugerem Greimas e Courtés (2008, p. 447) ao definir semiose. Esses autores acrescentam: "qualquer ato de linguagem [...] implica uma semiose" (p. 448). Os semioticistas ainda ressaltam que se pode entender como semiose "a categoria sêmica da qual os dois termos constitutivos são a forma da expressão e a forma do conteúdo (do significante e do significado)" (p. 448). O blog é um ato de linguagem, logo implica uma semiose. Resta saber como ele se compõe, como signo-texto, segundo uma forma (do conteúdo e da expressão), que radica a substância (do conteúdo e da expressão). Entre os planos da expressão e do conteúdo, resta também 
saber como no blog é ressaltada a relevância da textualização.

0 intento de examinar a semiose no blog Kibeloco acaba por viabilizar a observação que se faz da edição do blog congelada para análise. Mas essa edição única e congelada sempre traz consigo uma totalidade massiva, enquanto a noção de totalidade remete à ideia de recorrência do dizer e do dito. Então a observação analítica - que emparelha o exame que se faz dos mecanismos de construção do sentido no enunciado, à descrição que se faz das marcas da enunciação enunciada - permite reconhecer um modo recorrente de dizer, fundamento do corpo do ator. Cada edição de um blog como uma unidade textual, tal qual apresentada no dia de acesso ao site, confirma-se como um todo organizado de sentido, que vem à luz por meio dos mecanismos que contemplam um plano do conteúdo e um plano da expressão. A inclinação à abertura mantém-se como efeito de sentido.

Assim examinado, o blog pode ser descrito no seu funcionamento discursivo como um enunciado, que pressupõe uma enunciação e que se emparelha a regras de uma "cena genérica”, própria ao gênero (MAINGUENEAU, 2006). Materializado na textualização eletrônica, em formato próprio à tecnologia digital, o enunciado - que se apresenta como o blog acessado e vindo à luz graças a uma leitura definida em gradação da co-enunciação (mais participação interventiva ou menos) é mais dependente ou menos da leitura que acompanha, de modo crescente ou decrescente, o gesto de inserir postagens.

Tais movimentos não afastam um efeito de cumplicidade na instância de produção e leitura, o que aproxima entre si os enunciadores: aquele que assina o blog; aquele que assina comentários e assim por diante. Aproximam-se os enunciadores reunidos também segundo a convergência e mesmo segundo a divergência de pontos de vista das postagens. Essa 
proximidade faz com que se afirmem as co-presenças na relação de contiguidade estabelecida entre elas. Enquanto isso, o blog, radicado como totalidade de textos, configura-se inteiro, na medida em que é respeitado seu caráter de mobilidade, favorecedor de co-presenças. Em cada texto, no plano da expressão, a materialidade das manifestações das linguagens e, no plano do conteúdo, o percurso gerativo da significação; entre cada plano, a textualização, que comporta em si coerções de ambos os planos.

Por sua vez, cada edição do blog - considerada uma unidade, um enunciado ao qual está pressuposta uma enunciação bipartida entre enunciador e enunciatário, autor e leitor grosso modo - apresenta marcas da totalidade que sustenta o próprio blog como um "enunciado relativamente estável" (BAKHTIN, 1997) ou como um gênero discursivo: são regras composicionais, orientações temáticas, e é o tom ou o estilo do gênero. Firma-se como fundado na semiose de seus textos, o gênero cravado no ciberespaço, essa rede baseada em meios próprios à interconexão mundial dos computadores; essa rede em que sujeitos enunciam ao navegar, configurando e reconfigurando tal espaço, o que nos faz deparar com práticas discursivas, que, sociais por excelência, implicam na constituição do corpo do enunciador-blogueiro como um campo de presença.

No Kibeloco, o exame que se faz da semiose - como correlação entre a forma do conteúdo e a da expressão dos textos que compõe o blog - beneficia-se das noções tensivas de descontinuidade e continuidade. Antes, porém, Hjelmslev (1991) nos ampara nas tentativas de uma descrição do sentido voltada para a semiose no blog. Ao fazer considerações sobre a substância do conteúdo, o linguista dinamarquês fala em: "uso semântico adotado em uma comunidade linguística"; "avaliações adotadas por essa comunidade"; "apreciações 
coletivas" (p. 63) e acrescenta: "A descrição da substância [do conteúdo] deve, pois, consistir antes de tudo numa aproximação da língua às outras instituições sociais e constituir o ponto de contato entre a linguística e os outros ramos da antropologia social” (p. 63). Se, no conteúdo, a avaliação respalda o conceito a que se chega (a substância) a partir das relações categoriais que radicam a forma como a organização articulada e arbitrária da significação, entendemos que permeia a forma e a substância o crivo ou a visada - próprios ao sujeito.

Da forma do conteúdo do blog, despontam, para firmar diferencialmente o estilo do gênero em relação a uma crônica da mídia impressa, por exemplo, figuras actoriais como a do internauta convidado a participar com intervenções. Não custaria examinar, para descrever a diferença, a crônica de origem impressa e um blog, ambos assinados por Fernando Rodrigues $^{20}$. Ainda, para firmar a diferença que pauta o estilo autoral, despontam, do enunciado do Kibeloco, figuras actoriais expostas de modo peculiar à avaliação satírica. 0 cotejo entre um blog de humor e outro pode desenvolver a análise do estilo autoral. Cada figura do discurso de Kibeloco, por sua vez, respalda-se num objeto de valor desejável, vinculado a regimes de valores de absoluto ou de universo levados em consideração sob um "parâmetro tensivo" (FONTANILLE; ZILBERBERG, 2001, p. 54). Da relação de pressuposição recíproca entre unidades do nível discursivo (figuras), e as do nível narrativo (objeto de valor) permeadas por medidas de valor (valências) como a mistura e a triagem, desponta a forma interna à geração do sentido (plano do conteúdo).

20 Um exemplar de crônica, de autoria Fernando Rodrigues, intitulada Steve Jobs e o Brasil (Folha de S. Paulo, Opinião, 8 de outubro de 2011) está disponível em: 〈http://edicaodigital.folha.com.br/home.aspx〉. Acesso em: 16 dez. 2015; um exemplar do blog do mesmo autor pode ser encontrado em: http://fernandorodrigues.blogosfera.uol.com.br/〉. Acesso em: 16 dez. 2015. 
Acontece que, paralelamente à semântica dos valores axiologizados como da mistura ou da triagem e dos objetos modalizados segundo valores desejáveis ou prejudiciais (GREIMAS, 2014, p. 109), também se processam os valores tensivos, que não estão presos a nível algum da geração do sentido. Esses valores tensivos, que vêm das profundidades figurais, passam pelo percurso gerativo do sentido e, por isso, podem ultrapassar o conteúdo e atingir o plano da expressão. São valores que - orientados pela "força que transporta as categorias semânticas" (TATIT, 2002, p. 199) ou pela foria, concebida na acepção dessa força - podem ser compreendidos pelo plano da expressão. A partir da movimentação sintáxica que respalda ainda as pré-condições da geração do sentido, eles atingem o plano da expressão, já que não carregam em si carga semântica. 0 sincretismo, que ocorre no blog entre diversas linguagens de manifestação, ou entre diferentes substâncias do plano da expressão sincretizadas, é um exemplo. 0 "enunciado sincrético" comentado por Floch (GREIMAS; COURTÉS, 1986, p. 218) compreende - de acordo com a "estratégia, global, de comunicação sincrética que 'gera' [...] o contínuo discursivo que resulta da textualização" uma única enunciação, o que enfatiza a prioridade dada a esse "contínuo discursivo". Na união sincrética entre as diversas linguagens de manifestação firma-se a preferência pela continuidade entre elas, o que é legitimado pela noção de uma única enunciação sincrética. Mas a continuidade não é algo em si, é um valor, logo é relacional. É um valor que organiza a forma da expressão dos textos. Para isso está radicada na oposição continuidade vs. descontinuidade, respaldo da forma da expressão. Tais valores apresentam-se segundo um parâmetro tensivo, que vem das profundidades figurais para radicar-se no plano da expressão, organizando sua forma. 
Da forma do conteúdo que sustenta, nos textos, o corpo do blogueiro, despontam, juntamente com a sintaxe e a semântica próprias ao percurso da geração do sentido, oposições como aquelas relativas à relação sintáxica estabelecida entre valores tensivos, trazidos à luz nos quadros registrados por Tatit. Vimos que o lugar privilegiado para o corpo blogueiro é a parada da parada, o que o confirma como um corpo móvel. Na forma da expressão dos enunciados do blog também pode ser levada em consideração a oposição entre a dêixis da continuidade, que podemos chamar de A (continuação da continuação, S1, e parada da parada, não-S2), e a dêixis B, da descontinuidade (continuação da parada, S2, e parada da continuação, não-S1). Naquela dêixis (A), homologada às articulações da foria como eufórica, ancora-se também a forma da expressão dos textos que compõem o blog, para, na substância da expressão, radicar a preferência pela continuação no sincretismo consumado entre as distintas linguagens de manifestação. Não separado de tais relações sintáxicas entre valores tensivos, na textualização firma-se também o hipertexto, voltado para a materialização do que é massivo, logo não contável, o que remete a certo contínuo. Concomitantemente, a substância do conteúdo do blog Kibeloco reporta-se ao conceito de um mundo ao revés, na impregnação feita pelo humor e na alternância rítmica entre a exclusão e a mistura: aquela projetada pelas avaliações pejorativas, enquanto esta, ao confirmar-se como respaldo geral do modo de dizer do blog, faz da ambiguidade do riso uma aliada.

\section{Notas finais}

Por meio dos mecanismos de construção do sentido 
próprios ao enunciado do blog, o blogueiro dá a entender o que temos deduzido do seu próprio corpo. Não levamos em conta, portanto, pessoas pré-existentes ao discurso. Junto aos movimentos de informar e de opinar no interior do blog, confirmam-se características que compõem a competência discursiva desse blogueiro, articulada no domínio da chamada informação virtual.

Essa virtualização é fonte indefinida de atualizações, como sugere Lévy (2011), ao explicar o virtual no universo da informática. A virtualização como modo de apresentação da materialidade do blog se torna item definidor da textualização dos enunciados na Web. Lévy acrescenta que o virtual no universo on-line é o que "existe sem estar presente" (2011, p. 50). Ao trazer para o âmbito dos estudos discursivos essa acepção de informação virtual e respeitada a semiose, deparamo-nos - na relação entre plano da expressão e plano do conteúdo, e levada em conta a textualização - com enunciados em mutação, juntamente com corpos enunciativos em mutação, na pressuposição recíproca entre o realizado e o virtual (no dito e no dizer), com relevância, na definição do corpo blogueiro, para o polo do atualizado (complementar ao realizado). Assim parece vir à luz o horizonte de percepção e de axiologização dos valores que enformam o mundo posto em discurso na rede interativa da internet.

Tangenciamos sempre coerções ao proceder à análise. Elas são sistemas de restrições semânticas, tensivas e materiais, que respaldam a estabilidade em que se radica o plano da expressão, o plano do conteúdo e a textualização, esta que se interpõe entre eles. Lévy, ao afirmar que "a densidade dos links entre as informações aumenta vertiginosamente nos bancos de dados", sugeriu um princípio de caos e de anarquia no discurso da internet. Mas esse princípio de caos e de anarquia destacados por Levy confirmam-se como um efeito 
de sentido, fundado na regularidade e organização do modo de dizer. Entre as coerções está também a materialidade do suporte. Concebido no âmbito da textualização do discurso, apresenta-se no blog o suporte fluido, marcado por links "que podem ser explorados em tempo real na tela", como diz Lévy (2011, p. 27). Do pensamento do pesquisador, ficamos com a noção de mobilidade para entender a fluidez do discurso e de sua materialidade levada a cabo pelo suporte digital, que, na textualização, crava o blog no limiar entre o plano do conteúdo e o plano da expressão.

A mobilidade do suporte, alavancada pelo hipertexto, reverbera no plano do conteúdo e passa a aspectualizar a enunciação enunciada no blog, como a presença móvel e como a presença que produz e alonga o movimento. Assim a enunciação pode ser definida também segundo um ator aspectualmente cinético (na etimologia do termo está o grego kinétikós,ê,ón - móvel, que produz movimento). Estamos diante de uma textualização que recria em si: um sistema de restrições semânticas (próprio à forma do plano do conteúdo); um sistema de restrições tensivas (próprio à forma do plano da expressão), do que se depreende um dos movimentos da semiose. Tudo é norteado, na textualização, pelo princípio da mensagem em rede móvel que caracteriza o hipertexto.

“'Blogar' permite que haja um diálogo de mão dupla em um fórum público, liderado por pessoas reais" - disse Terra (2012, p. 21); temos links, "que podem ser explorados em tempo real na tela" - disse Lévy (2011, p. 27). Os conceitos de "tempo real" e de "pessoas reais" ostentados fica então problematizado sob uma perspectiva que conduz à retórica do blog. O blogueiro, nessa perspectiva, é firmado como um éthos, com corpo, voz, tom de voz e caráter - um enunciador, cujo modo de dizer é recuperável na análise que contempla, para o plano do conteúdo, o percurso gerativo da significação bem como as pré- 
-condições da geração do sentido; para o plano da expressão, a materialidade sincrética das diversas linguagens fundamentada no "contínuo discursivo" que suscita o próprio sincretismo, baseado por sua vez nas articulações formais entre o contínuo e o descontínuo. Entre os dois planos, a análise contempla a textualização que, organizada segundo o hipertexto, contribui para que se componha o suporte material do blog.

Antes de concluir, observamos que um efeito de aumento de intensidade ou uma tonificação da crítica social certamente fica corroborado, na medida em que o tom da crítica cumulativamente se alonga de um post para outro ao longo do blog Kibeloco. Volta à luz aquilo que Fontanille e Zilberberg (2001, p. 59) apontam como um ponto de vista que privilegia a "antecâmara da exclusão", sustento da pejoração. Mas o riso, como efeito de sentido, restaura em parte a relatividade da avaliação pejorativa. Já a partir da "memória esquemática" que funda o modo de presença do blog, sentimos que não é puramente negativo o tom adotado pelo chargista. $\mathrm{O}$ efeito de ambivalência permanece. Há a sanção moral, na qual se aloja a sátira, mas um resíduo de relativização da "exclusão" permanece. Foram miradas pela sátira as figuras de Lula e de Dilma. Bakhtin (1987, p. 210) fala no "papel do rei destronado", concernente à autoridade ridicularizada pelo riso popular. Ressalta então a relevância do riso ambivalente no trato com a imagem da mulher, em certa tradição, para o que começa por afirmar:

É preciso sublinhar que na "tradição gaulesa" a imagem da mulher, como todas as outras, é apresentada sob o ângulo do riso ambivalente, ao mesmo tempo brincalhão e destruidor, alegre e afirmador. Pode-se, nesse caso, assegurar que ela faz um julgamento hostil e negativo sobre a mulher? Certamente que não. A imagem da mulher é ambivalente, como todas as da "tradição gaulesa". 
Mas, quando essa imagem é utilizada pelas tendências ascéticas do cristianismo ou pelo pensamento abstrato e moralizador dos autores satíricos e moralistas dos tempos modernos, ela perde o seu polo positivo e torna-se puramente negativa (BAKHTIN, 1987, p. 210).

A memória que se mantém como potencialização do sentido nos enunciados do blog Kibeloco e como potencialização do corpo do ator da enunciação prepara-nos não para algo definitivamente moralizador, nem tampouco para o chargista como um definitivo moralista dos tempos modernos. Nada se apresenta como definitivo no interior do discurso processado na internet. Em relação ao Kibeloco, cremos poder obter a semantização da pessoa, do tempo e do espaço dos enunciados do blog - processada na ordem da ambivalência cômica, "degenerada", porém, em relação ao riso estudado por Bakhtin. Essa constatação é feita a partir do que diz o próprio Bakhtin em sequência à citação anteriormente feita. Ao referir-se a uma espécie de deformação que a imagem da mulher da "tradição gaulesa" teria sofrido principalmente no século XVIII, afirma o russo: "Ela [a imagem da mulher gaulesa] torna-se então negativa, ou então sua ambivalência degenera em mistura insensata de traços negativos e positivos" (p. 210).

Bakhtin (1987, p. 210) sugere que, quanto maior for a "verossimilhança realista", quanto maior for a "semelhança com a vida", mais contundente será essa degeneração. Logo, deduzimos que maior será a força da moralização. Levando em conta essa "verossimilhança realista", concluímos que, nas charges que retomam o quadro histórico de Pedro Américo, a degeneração do riso ambivalente diminui, já que a charge é feita a partir de uma obra de arte. É diferente o que acontece na charge que traz à luz a bricolagem feita a partir da foto midiática dos bonecos infláveis. Embora o efeito de ficção seja 
aí favorecido pelas falas irreverentes encerradas nos balões, a "semelhança com a vida", ou a "verossimilhança realista" é maior, pois a fonte é a fotorreportagem. Por sua vez, na reprodução dos vídeos do anão em festa de repartição pública e do "Quero Sílvio", o corpo do ator do enunciado (Sílvio Santos, o anão e os funcionários públicos) ganha ainda maior "semelhança com a vida". Nesse ínterim, oscila o corpo do blogueiro para um grau mais elevado de degeneração do riso ambivalente. Por meio dessa inflexão, que é rítmica, instaura-se o modo de existência pautado por uma triagem apresentada entre intervalos de maior ou de menor força e tonicidade. Tudo se passa na alternância de movimentos, que corrobora o ritmo.

A possibilidade de contemplar os sistemas da triagem e da mistura segundo a gradação de uma maior ou menor tonicidade ou acento de sentido pode contribuir para a análise do corpo como um campo de presença. Em relação ao blog Kibeloco, cremos poder deduzir a mistura tonificada: na sintaxe discursiva, já por meio da aglomeração existente entre instâncias enunciativas; na semântica discursiva, entre atores que se mantêm na reunião de papéis temáticos afins ou contrastantes; na textualização, processada por meio do hipertexto; no plano da expressão, que inclui o sincretismo entre linguagens diversas, bem como articulações formais entre o contínuo e o descontínuo. Alternadamente, a exclusão é tonificada, via: uma avaliação pejorativa beneficiada pela sátira; uma redução significativa do "riso ambivalente e regenerador"; um dever ser que modaliza a competência discursiva do blogueiro. Esse dever compor-se no modo da difusão midiática acaba por robustecer semanticamente o corpo no papel estereotipado de mediador, e, ao fazer isso, tal dever inclina à unilateralidade deôntica o sujeito que percebe e o mundo percebido. Entretanto resta no Kibeloco a movimentação alternada entre a tonificação da mis- 
tura e a da exclusão, em ritmo que compõe um estilo blogueiro de fazer humor.

\section{REFERÊNCIAS}

AUTHIER-REVUZ, J. Hétérogéneité montrée et hétérogéneité constitutive: élements pour une approche de l'autre dans le discours. DRLAV, 26. Paris, Centre de Recherche de l’Université de Paris, VIII, 1982, p. 91-151.

BAKHTIN, M. A cultura popular na Idade Média e no Renascimento. 0 contexto de François Rabelais. Trad. Yara Frateschi Vieira. São Paulo: HUCITEC; [Brasília]: Editora da Universidade de Brasília, 1987.

BAKHTIN, M. Estética da criação verbal. Trad. Maria Ermantina Galvão G. Pereira. 2. ed. São Paulo, Martins Fontes, 1997.

BERTRAND, D. Variations sur le tournant phénoménologique en sémiotique. Cópia de Conferência proferida na Pontíficia Universidade Católica de São Paulo, em versão xerocopiada cedida pelo autor. São Paulo, 18 de agosto de 2015.

DISCINI, N. 0 estilo nos textos. 2. ed. $1^{\text {a }}$ reimpressão, São Paulo: Contexto/FAPESP, 2015a.

DISCINI, N. Corpo e estilo. São Paulo: Contexto/FAPESP, 2015b. 
FIORIN, J. L. As astúcias da enunciação. As categorias de pessoa, espaço e tempo. São Paulo: Ática, 1996.

FONTANille, J.; ZILBERBERG, C. Tensão e significação. Trad. Ivã Carlos Lopes; Luiz Tatit e Waldir Beividas. São Paulo: Discurso Editorial Humanitas/ FFLCH/USP, 2001.

GREIMAS, A. J. Sobre o sentido II. Trad. Dilson Ferreira da Cruz. São Paulo: Nankin: Edusp, 2014.

GREIMAS, A. J.; COURTÉS, J. Dicionário de Semiótica. Trad. Alceu Dias Lima et al. São Paulo: Contexto, 2008.

GREIMAS, A. J.; COURTÉS, J. Sémiotique. Dictionnaire raisonné de la théorie du langage. Tome 2. Paris: Hachette Université, 1986.

HJELMSLEV, L. Ensaios linguísticos. Trad. Antônio de Pádua Danesi. São Paulo: Perspectiva, 1991.

HJELMSLEV, L. Prolegômenos a uma teoria da linguagem. 2. ed. Trad. J. Teixeira Coelho Neto. São Paulo: Perspectiva, 2003.

HOUAISS, A. Dicionário Houaiss da língua portuguesa. Rio de Janeiro: Objetiva, 2009.

LÉVY, P. Cibercultura. 3.ed., 1a Reimpressão. Trad. Carlos Irineu da Costa. São Paulo: Editora 34, 2011.

MAINGUENEAU, D. Cenas da enunciação. Trad. Maria Cecília Pérez de Sousa-e-Silva et al. São Paulo: Criar, 2006 [Organizado por Sírio Possenti e Maria Cecília Pérez de Souza-e-Silva]. 
MARCUSCHI, L. A. Gêneros textuais emergentes no contexto da tecnologia digital. Hipertexto e gêneros digitais. Novas formas de construção do sentido. 3. Ed., 1ํㅡㄹ Reimpressão. São Paulo, Cortez, 2010.

SAUSSURE, F. Curso de linguística geral. 2. ed. Trad. Antônio Chelini; José Paulo Paes e Izidoro Blikstein. São Paulo: Cultrix, 1970.

TATIT, L. Abordagem do texto. In: FIORIN, J. L. (Org.). Introdução à linguística. São Paulo: Contexto, 2002. v. I, p. 187-209.

TERRA, F. C. Blogs corporativos: modismo ou tendência? 2.ed. São Caetano do Sul, SP: Difusão Editora; Rio de Janeiro: Senac Rio, 2012.

ZILBERBERG, C. Razão e poética do sentido. Trad. Ivã Carlos Lopes; Luiz Tatit e Waldir Beividas. São Paulo: Edusp, 2006.

ZILBERBERG, C. Elementos de semiótica tensiva. Trad. Ivã Carlos Lopes; Luiz Tatit e Waldir Beividas. São Paulo: Ateliê Editorial, 2011.

Artigo recebido em setembro de 2015 e aprovado em novembro de 2015.

Disponível em: http://seer.fclar.unesp.br/casa 